\title{
Sue Prideaux
}

Jeg er dynamit! Friederich Nietzsches liv. Oversat af Joachim Wrang, Aarhus: Forlaget KLIM 2020. 468 s. Kr. 349,95.

Allerede i 1975 kunne italienske Mazzino Montinari i indledningen til sin egen og dermed endnu en biografi om den tyske filosof Friedrich Nietzsche tørt konstatere, at næppe nogen anden tænkers personlige liv er blevet endevendt med så stor nysgerrighed og analyseret under så forskellige perspektiver som Nietzsches - og i de efterfølgende lidt over 40 år siden Montinari skrev dette, er listen med værker om denne tænker, der var utidssvarende for hans egen samtid, men hvis betydning for og indflydelse på det 20. århundredes ånds- og kulturliv ikke kan overdrives, udvidet betragteligt. Senest kan vi på dansk glædes os over den letlæselige, men sprudlende danske version af den anglo-norske forfatter Sue Prideaux' Jeg er dynamit! Friedrich Nietzsches liv. Spørgsmålet er dog, om Prideaux med sin Nietzsche-biografi formår at bevare endnu ubesvarede spørgsmål, der utallige biografier til trods stadig fordunkler en forklaring af Nietzsches vigtige livsafsnit: Hans evige gentagelse af forsøg på afsked med moren og søsteren og den aldrig succesfulde afsked med afskeden; tiderne med Richard og Cosima Wagner, Paul Rée og Lou Solomé, sygdommen og faderens - alt for - tidlige død. Kaster Prideaux med sin essentielle biografi, som ifølge bagside ønsker at forstå filosoffen, et nyt forklarende lys over Nietzsche?

Både ja og nej! Ja, for så vidt Prideaux i bogen forholder sig strengt til det biografiske stof; nej, som konsekvens af en manglende overordnende anden læsning af Nietzsches liv end en kronologisk. Bortset fra indledningen til første kapitel, der starter in medias res den 9. november - hvilken skæbnes dato skulle dette ikke senere vise sig at blive i Tysklands ulykkelige historie 1868, den dag hvor en 24-årig ung, filologstuderende Nietzsche for første gang møder sit store forbillede: Richard Wagner, præsenteres Nietzsches liv 
fra vugge til til grav kronologisk i 22 kapitler. Effekten af det lille, indledende spring i kronologien er, at Prideaux opbygger en traditionel rammefortælling om musikkens betydning i Nietzsches liv og virkningsfuldt kan bygge hans (ud)dannende år op til han i 1869 takker ja til et tilbud om et professorat i Basel, ikke langt fra Tribschen, hvor Wagner bor, og Nietzsche for første gang aflægger ham et uventet besøg d. 15. maj. Livet sammen med Wagner og Cosima skildres i kapitlerne 3-8. Herefter følger kapitlerne 9-13, hvori der berettes om de frie ånders, Rée, Lou og Nietzsche, samliv. Vi er nået til 1883, året, hvor Min far, Wagner, er død. Min søn Zarathustra er født. Zarathustra-bogen behandles i kapitler 14-16, mens 80'er manuskripterne tildeles kapitlerne 17-20. Endelig hører vi om Nietzsches sammenbrud i kapitel 21, mens kapitel 22 beretter om falskmønteren Elisabeths arbejde med at sikre sig ene- og råderet over brorens œuvret.

Prideaux' valg af en kronologisk frem for f.eks. en tematisk strukturering gør bogen både læsevenlig, og for læsere uden det store kendskab til Nietzsche vil den være en oplagt indføring til såvel Nietzsche som til de vigtigste personers i hans liv; men netop hans liv og ikke hans tanker og tænkning. Prideaux afstår bort set fra ganske få steder at tolke Nietzsche, men nøjes udelukkende med blot at citere ham. Flere steder anføres længere citater uden tolkende kommentarer (334-335 \& 343-344). Desuden undres man også over bogens titel: Jeg er dynamit! Er der noget Nietzsche ikke er i Prideaux' fremstilling er det springfarlig, tværtimod gør hun en dyd ud af at portrættere ham som et blidt og kærligt menneske, f.eks. i forbindelse med bruddet med Rée og Lou. Her omtales Rée som "bedragerisk" og "fræk", mens "Nietzsche, som altid var tilgivende og overbærende, skrev til Lou, at han tilgav hende" (246).

Prideaux er afgjort bedst i bogens sidste og længste kapitel, hvori der berettes dels om Nietzsches sidste 11 år i sindssygens mørke, dels om den mindst lige så gale antisemit Elisabeths forsøg på at ødelægge sin brors eftermæle ved at tilpasse ham til sit eget forskruede nationalsocialistiske verdensbillede. Kapitlet er også mere kultur- og idéhistorisk anlagt end bogens øvrige, og her er Prideaux, der også har skrevet biografier om Edward Munch og August Strindberg, tydeligvis på hjemmebane. Hun kender tidens tanker og evner at formidler dem i et tilgængelig og let forståligt sprog. Da bogen er alt andet end tung og akademisk, egner den sig afgjort til ferielæsning, da man kan lægge den fra sig og nemt vende tilbage til den, når tiden og lysten igen er der. 